\title{
Välittömyyden myytti ja ihmiskuva
}

\begin{abstract}
Eskola, Antti. 1982. Välittömyyden myytti ja ihmiskuva. Aikuiskasvatus 2, 1, 11-13. - Artikkelissa tarkastellaan ihmiskuvaan liittyviä ongelmia sosiaalipsykologian näkökulmasta. Tarkoituksena on selvittää välittömyyttä ihmisten välisessä vuorovaikutuksessa, ns. intiimisyyden myyttiä ja ihmisenä olemisen ongelmia. Pyrkimykset ihmissuhteiden ja inhimillisen vuorovaikutuksen kehittämiseen nähdään haasteena aikuiskasvatukselle.
\end{abstract}

Koska en ole aikuiskasvattaja, tuntuisi keinotekoiselta pohdiskella ihmiskuvaproblematiikkaa nimenomaan aikuiskasvatuksen näkökulmasta. Mutta ehkä se ei ole tarpeenkaan. Kenties on avartavaakin aikuiskasvattajien lehdessä katsoa, miten jonkin lähitieteen tässä tapauksessa sosiaalipsykologian - edustaja joutuu miettimään ihmiskuvaan liittyviä ongelmia omassa työssään, olkoonkin että kyse on lähinnä tutkimustyöstä. ${ }^{1}$

Sellaiset yleiset pohdinnat, joita toimituksen esittämät kysymykset ehkä ovat omiaan virittämään, herättävät minussa pienen pelon, että ihmiskuvapohdiskelut irtautuvat käytännön todellisuudesta. Tällöin helposti syntyy rakenne, joka muistuttaa sitä, mitä korkeakoulututkimuksessa on kutsuttu piilossa olevaksi opetussuunnitelmaksi (the hidden curriculum): yhtäällä viralliset tavoitteet kuten tieteellinen ajattelu, luovuus jne.; toisaalla varsinainen opetus- ja tutkintojärjestelmä, joka suosii epätieteellistä tietojen mekaanista ja epäluovaa mieleenpainamista. Samalla tavoin tutkija tai kasvattaja voi käytännön työssään toimia aivan eri ihmiskuvan pohjalta kuin mitä hän puheissaan ja kirjoituksissaan esittää - huomaamatta edes itse ristiriitaa. Siksi laistan suoran vastaamisen ja yritän lähestyä problematiikkaa pikemminkin kautta rantain.

\section{Inhimillisen toiminnan välittymismekanismit}

Tässä lyhyessä kirjoituksessa nostan esiin vain yhden ihmiskuvaan liittyvän seikan tai ulottuvuuden, nimittäin sen, kuinka paljon ihmisen tiedostusta ja toimintaa kuvaavissa malleissa annetaan sijaa erilaisille välityksille.
Otan heti esimerkin:

Yhdysvalloissa tehtiin 1930-luvulla joukko sentyyppisiä kokeita, joissa koehenkilöille jaettiin eräänlaisia aforismeja sisältävä kyselylomake. Kustakin ajatelmasta oli mainittu, kuka tunnettu henkilö sen oli lausahtanut. Koehenkilöä pyydettiin merkitsemään kunkin aforismin kohdalle hyväksyikö hän tuon ajatuksen vai ei.

Henkilöt eivät tienneet, että he saivat hiukan erilaisia lomakkeita. Ajatelma, joka yhdessä lomakkeessa oli merkitty esimerkiksi Thomas Jeffersonin sanomaksi, saattoi toisessa esiintyä V.I. Leninin lausumana. Edellisessä tapauksessa henkilöt hyväksyivät lauseen useammin kuin jälkimmäisessä. Ilmiö selitettiin sillä, että amerikkalaisessa opiskelijassa hänen maansa entisen presidentin nimeen on ehdollistunut positiivisia ja Leninin nimeen negatiivisia tunteita. Ehdollistuneen reaktion yleistymisen myötä myös Jeffersonin lausumaksi luultu ajatus herättää hyväksyvän reaktion ja Leninin lausumaksi luultu ajatus torjuvan reaktion aivan yhtä välittömästi kuin Pavlovin kuuluisissa koirakokeissa ruokaan ehdollistettu äänimerkki saa koiran syljen valumaan.

Solomon E. Asch toisti 40-luvulla tämän kokeen sillä lisäyksellä, että koehenkilöitä pyydettiin lopuksi kirjoittaaman pieni essee kunkin ajatelman sisällöstä. Eräs aforismi kuului suunnilleen seuraavasti: '’Pieni kapinointi silloin tällöin on vain hyväksi ja poliittiselle maailmalle yhtä tarpeellinen kuin mitä myrskyt ovat fyysiselle maailmalle". Luullessaan lau-

\footnotetext{
${ }^{1}$ Tässä esitettävät ideat nousevat työstä, joka kuluvana vuonna ilmestynee kirjana nimeltä Vuorovaikutus, muutos, merkitys (kustantajana Tammi, Ruotsissa Almqvist \& Wiksell).
} 
setta Jeffersonin sanomaksi koehenkilöt olivat hyväksyneet sen useammin kuin luullessaan sitä Lenin-sitaatiksi. Mutta kyse ei ollutkaan vain ehdollistuneen reaktion yleistymisestä. Esseet nimittäin osoittivat, että koehenkilöt olivat tulkinneet ajatelman eri tavoin riippuen siitä, kenen sanomaksi he sitä luulivat. Jeffersonin lausumana sanan 'kapinointi' ' ajateltiin tarkoittavan vaaleissa ilmaistua poliittista protestia, Leninin lausumana vallankumousta. Koehenkilöt eivät reagoineet Pavlovin koirien tapaan siihen ärsykelauseeseen joka heidän eteensä pantỉn, vaan he tulkitsivat lauseen ja reagoivat itse asiassa eri ärsykkeisiin. Vaikutus ei tapahtunut välittömästi ja mekaanisesti vaan kognitiivisten tekijöiden välittämänä.

Kun puhutaan ihmiskuvasta yleisesti, on kai toki jokaisen pakko myöntää, että ihminen on ajatteleva, tiedostava, merkityksiä antava ja niihin reagoiva sekä tässä kaikessa kieltä välineenä käyttävä olento. Sama myöntäjä saattaa kuitenkin puolustella jotain sosiobiologista hömpötystä, jonka pohjalta löytyy otaksuma, että ihmisen toimet muka olisivat yhtä välittömästi ja mekaanisesti laukeavaa reagointia avainärsykkeisiin kuin mitä eläinten vaistotoiminnat ovat.

Tietoisuuden välittävän merkityksen myöntävistä puheista huolimatta myös tieteelliset kokeet samoin kuin opetuskin usein rakennetaan tavalla, jonka pohjalta löytyy kätketty kuva mekaanisesti ja välittömästi reagoivasta ihmisestä. Koehenkilöiltä peitetään kokeen todellinen tarkoitus väärin instruktioin tai heitä puijataan soluttamalla heidän joukkoonsa kokeenjohtajan salaisia avustajia. Keskustelu ei ole sallittua; vastausreaktiot rajoitetaan vain napin painamiseen tai rastin piirtämiseen ruutuun. Näillä toimin tietoisuus ja kielen käyttö välineenä ' kontrolloidaan" ikään kuin ne olisivat vain koetta "häiritseviä"' tekijöitä. Samalla tavoin kontrolloidaan usein myös opetustilanteissa oppilaiden oma aktiivisuus. Jos se on hallinnassa - eli vain reaktiota opettajan tekoihin - se sallitaan ehkä yhtenä "'opetusmetodina"; muussa tapauksessa se määritellään häiriöksi.

Aschin kokeessa ärsykeinformaatio (aforismi) muuttuu eri koehenkilöiden tajunnassa eri tavoin ja siksi aiheuttaa heissä myös erilaisen reaktion. Tällä hetkellä vahvassa nousussa oleva kognitiivinen psykologia tutkii juuri tuollaisia ärsykeinformaation muunnoksia. Ehkä se on entistä vakuuttavammin tuomassa kognitiiviset välitykset ihmiskuvaamme.

Askelta pidemmälle menevää välittyneisyyttä tähdentää A.N. Leontjevin Toiminta, tie- toisuus, persoonallisuus, Kansankulttuuri 1977) persoonallisuuspsykologia, joka nostaa välittäväksi tekijäksi ihmisen yhteiskunnallisen toiminnan ja hänen yhteiskunnalliset, taloudellisen järjestelmän välittämät suhteensa. Sosiaalipsykologiaa on samaan suuntaan kehittämässä mm. ruotsalainen Joachim Israel $(\mathrm{Om}$ relationistisk socialpsykologi, Korpen 1979). Kumpikin yritys on esimerkki hedelmällisistä aineksista joita marxilainen ajattelu tuo ihmiskuvakeskusteluun, kun tätä ajattelua ei oteta valmiina oppina, vaan metodologisena näkökulmana ihmisen tutkimiseen.

\section{Välittömyys - intiimisyys}

Sosiaalipsykologiassa eli ihmisten välistä vuorovaikutusta tutkittaessa välittömyyden myyttỉ ilmenee myös sïnä muodossa, että erilaiset säännöt, normit ja roolit kuvitellaan suoran ja "aidon" kommunikaation poisheitettäviksi esteiksi. Esimerkiksi erilaiset ryhmätyömenetelmät näyttävät usein lähtevän käsityksestä, että roolien naamioiden, kohteliaisuussääntöjen yms. kulttuurikeinojen välittämät suhteet ovat ongelma, josta on päästävä suoriin ja välittömiin suhteisiin. Jos on ikävystynyt muihin, on rehellisyyden vuoksi haukoteltava vapaasti; jos tekee mieli loukata toista, on aitouden nimessä tehtävä se.

Mutta onko tämä ihmiskäsitys järkevä silloin kun puhumme pitkälle kehittyneen, sivilisoituneen yhteiskunnan ihmisistä?

Harjaannuttaminen paitsi välittyneeseen myös välittömään ilmaisuun ja kontaktinottoon saattaa hyvinkin olla paikallaan, kun kyseessä on selvästi terapeuttinen tai esimerkiksi taiteellinen koulutus. Mutta pitäisikö välittömyyttä kehittää ja suosia kaikissa yhteyksissä ihmisten läheisyyden lisäämiseksi (esim. yleinen sinuttelu)?

Amerikkalainen sosiologi Richard Sennett ón 1977 ilmestyneessä kirjassaan The Fall of Public Man kohdistanut eri muodoissa esiintyvään läheisyyspyrkimykseen kritiikkiä, joka soveltuu myös tässä tarkoitetun välittömyysideologian tai -myytin värittämään ihmiskuvan kriittiseen punnintaan. Hän toteaa, että ihmissuhteissa nykyään vaaditaan "avautumista" ja sitä, että saadaan selville millainen toinen ihminen "todella on". Asioiden merkitys punnitaan sillä, kuinka vahvoja välittömiä kokemuksia ja tunteita ne yksilössä herättävät.

Intiimisyyspyrkimys on ihmissuhteissa loppujen lopuksi kuitenkin rasite. "Koska jokai- 
nen minä on jossain mitassa kauhukabinetti, voivat sivistyneet suhteet ihmisten välillä kehittyä vain siinä laajuudessa kuin himon, ahneuden ja kateuden likaiset pikku salaisuudet pidetään sisään suljettuina", Sennett sanoo. Hän katsoo, että tavoitteena ihmisten välisissä suhteissa tulisikin olla "elää muiden kanssa" eikä pakonomainen pyrkimys "päästä lähelle heitä".

Tällöin keinoksi nousee intiimisyyden sijasta kohteliaisuus. Sillä Sennett tarkoittaa "toimintaa, joka suojaa ihmisiä toisiltaan ja kuitenkin sallii heidän nauttia toistensa seurasta." Kohteliaisuus on sitä, että "kohdellaan toisia ikään kuin he olisivat vieraita ja rakennetaan sosiaalinen side tämän sosiaalisen etäisyyden pohjalle". Kohteliaisuus on myös "naamion kantamista'. Naamioita ei tällöin nähdä esteinä, jotka on heitettävä pois läheisyyden edistämiseksi, vaan vuorovaikutuksen kehittyneinä välineinä, joita on mahdollista käyttää turvallisen sosiaalisen suhteen rakentamiseksi. Olisiko tässä virikkeitä myös aikuiskasvatukselle?

Leontjev valaisee subjektin, hänen käyttämiensä tiedostamisen välineiden ja tiedostamisen objektin välisiä suhteita kuvalla kirurgista, joka tutkii potilaan käsivarressa olevaa luotia. Ei hän tutki sitä työntämällä sormensa suoraan ja välittömästi ampumahaavaan, vaan koettimella, jonka avulla kohteesta on mahdollista tehdä hyvinkin herkkiä ja tarkkoja havaintoja.

Ihmissuhteissakaan tuskin kannattaa ihailla sellaista primitiivisyyttä, jossa työnnetään kourat toisen ihmisen sisimpään, jotta voitaisiin "suoraan" ja "välittömästi"' tunnustella. Millainen tämä "todella on"; tai jossa ihminen yrittää olla "avoin" ja levittää oman sisimpänsä toisen nähtäväksi ja tunnusteltavaksi. Sellainen ihmiskäsitys ei ota huomioon ihmisen historiallista kehitystä. Alkukantaisuuden taakseen jättänyt yksilö tavoittaa toisen yksilön ainoastaan niiden käyttäytymissääntöjen välityksellä, jotka sivistyksen myötä ovat kehittyneet. Niiden avulla voidaan kehittyneen ihmisen monimutkaisia ja ristiriitaisia tunteita ja tuntemuksia toista ihmistä kohtaan ilmaista tarkemmin, vivahteikkaammin sekä siten myös todenmukaisemmin eli rehellisemmin kuin ilmaisuna köyhällä "aitoudella".

\section{Ihmiselämän ongelmallisuus}

Välittömyyden myytti vääristää ihmiskuvaa helposti myös siltä osin kuin se ohjaa käsityksiämme tietämisen, tutkimisen ja opettamisen arvoisista asioista. Tällöin erehdytään ajattelemaan, että tärkeää on vain se, mitä yksilö välittömästi näkee ja kokee. Esimerkiksi elämäntapatutkimus ohjautuu pelkkään ihmisten "todellisen elämän" kuvailuun arkikäsittein tai haastateltavien omien repliikkien siteeraamiseen sellaisenaan, ilman teorian aineistoa jäsentävää ja pintaa syvemmältä valaisevaa välitystä.

Kuitenkin jo Eino Kaila tähdensi, että tieteelle ovat ominaisia arkielämälle suhteellisen vieraat teoreettiset käsitteet. Ei putoamisliikettä tutkivan fyysikon tehtävä ole kuvata elämyksiä, jotka liittyvät siihen kun kypsä omena putoaa maahan. Yhtä tarpeetonta yhteiskuntatieteilijän on tutkijana ryhtyä tehtävään, jonka runoilija osaa paremmin. Oikeaan ihmiskuvaan kuuluu myös oikea käsitys keinoista joilla ihminen tiedostaa maailmaa. Kasvattajan ja kouluttajan työltä virheellinen käsitys vie pohjan kokonaan pois.

Ihmisen sivilisaatiokehitys on yhdeltä tärkeältä osin ihmisen etääntymistä toimintansa kohteista, monenlaisten välittävien lenkkien ja mekanismien kasvamista näiden kahden väliin. Tämä on ihmiskuvassa pakko ottaa huomioon. Ihminen on toimintansa kohteista, toisesta ihmisestä ja lopulta myös itsestään vieraantunut ihminen. Välittömillä kokemuksilla ja tuntemuksilla ei maailmaa enää ymmärretä ja hallita. Välitysketjujen kasvaessa ja haarautuessa ympärillämme on yhä enemmän asiota, jotka eivät tuota henkilökohtaisia elämyksiä vaikka ovat erittäin tärkeitä ja vaikuttavat voimakkaasti elämäämme.

Juuri tästä seuraa vaarallinen paradoksi. Sosiaalisten välitysten lisääntyminen ja monimutkaistuminen sekä tämän vieraannuttavat ja passivoivat vaikutukset panevat ajattelemaan, että olisi tärkeää tavoittaa konkreettinen ihmisyksilö, tutkia ja kuvailla hänen arkielämäänsä ja -ajatteluaan. Mutta arkielämään ja -ajatteluun rajoittuminen yhtä hyvin kuin välittömästi koettavaan yksityismaailmaan sulkeutuminen estävät meitä lopullisesti ymmärtämästä ja hallitsemasta maailmaa, joka on ymmärrettävissä ja hallittavissa vain vahvoin ja tietoisesti kehitellyin teorian välinein, abstraktein mallein, ihmisen välittömän ajattelukapasiteetin ylittävin tietokonesimuloinnein ynnä muin koettimin.

Välittömyyden myytti ja siihen perustuva virheellinen ihmiskuva ovat viekotelleet harhaan. Ihminen on loukussa, vieraantuminen sinetöity. 